\title{
REAL ESTATE VALUE TAX BASED ON THE LATVIAN EXPERIENCE
}

\author{
Maria Hełdak, Assoc. prof., PhD \\ Wroclaw University of Environmental and Life Sciences \\ Department of Spatial Management, Poland \\ e-mail:maria.heldak@up.wroc.pl
}

\author{
Agnieszka Stacherzak, PhD \\ Wroclaw University of Environmental and Life Sciences \\ Department of Spatial Management, Poland \\ e-mail:agnieszka.stacherzak@up.wroc.pl
}

\author{
Vivita Baumane, Assoc. prof., PhD \\ Latvia University of Agriculture \\ Faculty of Rural Engineering \\ Department of Land Management and Geodesy
}

\begin{abstract}
The article deals with the subject of the planned real estate changes in Poland as viewed in relation to the solutions accepted in Latvia. The current basis for real estate tax is a set fee per $1 \mathrm{~m}^{2}$ of the estate's area established in a town council resolution, taking into account the maximum fees established by the Minister of Finances. Currently, the owners of real estates with identical area often pay the same tax regardless of the location, condition and function of the real estate formulated in the plan. The cadastral tax currently in preparation addresses these and other features which influence the value of real estate. A set cadastral value approximate to the market value will serve as the basis for determining the cadastral tax. The principles of real estate tax retrieval in Poland are not clearly established which is why it might prove useful to use the experience of other countries undergoing similar governmental changes. The article makes references to tax solutions recognized in Latvia in the domain of tax fees, valuation principles and problems accompanying real estate tax retrieval.
\end{abstract}

Key words: cadastral tax system, real estate taxation.

JEL Classification: H24, H71.

Citation: Hełdak M., Stacherzak A., Baumane V., 2014, Real estate value tax based on the Latvian experience, Real Estate Management and Valuation, vol. 22, no. 4, pp. 60-67.

DOI: 10.2478/remav-2014-0037

\section{Introduction}

The 1990s saw the beginning of political transformations and the initiation of the process of adapting laws related to real estate economy to the new economic conditions. During this time market principles were introduced into real estate trade and the state began regulating laws regarding real estate ownership. Legal persons have been enfranchised, companies have been privatized and new ownership transformations have been introduced in the area of agricultural economy. Finally, market principles have been transferred onto the real estate economy (ŹRÓBEK et al. 2006). 
At around the same time, certain changes were introduced in the real estate tax system. On 12 January 1991 the parliament adopted an act regarding taxes and local fees (i.e. 2010 Journal Of Laws, no. 95 , item 613 as amended), which normalized matters related to real estate tax. The current basis for real estate tax is a set fee per $1 \mathrm{~m}^{2}$ of the area of the real estate. The size of the fee is determined by the individual town councils and accounts for maximum fees established by the Minister of Finances. The size of the tax depends on the fee established in the resolution of the town council, the manner in which the real estate or part of it is used and the area it occupies.

There are those who claim that this type of tax system is unfair and additionally leads to a situation in which real estate owners whose properties are based in attractive locations do not take proper care of their possession, as they cannot afford to ensure their continuous high standard. A shift in the tax system towards the cadastral tax has been planned in Poland for the last 14 years. A set cadastral value, similar to the market value, would serve as the basis for determining the cadastral tax.

The experiences of many highly developed countries indicate that this sort of solution is justified and can be successfully applied. It serves as a sort of objection to the inappropriate allocation of capital in space (HOZER, КОКОт 2005). Reducing the tax burden on improvements would facilitate revitalization and the replacement of obsolete buildings in older city centers. "Property owners, responding to the financial inducement to reduce the land-to-building value ratio, would build more intensively on vacant and underutilized sites. The cumulative effect over time and space would be to increase property values, and thus the tax base, where that is most needed." In urban areas this means building upwards and putting more buildings on smaller lots (GIHRING 1999).

An opposing theory challenges the view that a land value tax is an anti-sprawl tax and suggests that, under certain conditions, the land value tax has no more effect on urban sprawl than does the traditional property tax (SKABURSKIS 1995).

It is also hard to deny that a change within the real estate tax system is in the best interest of the municipalities. As proven by a number of conducted studies, current revenues from real estate tax constitute about one-third of the total income of municipalities, with as much as $70 \%$ observed in the Netherlands (KRAWCZYK 2009; HEŁDAK 2009).

Property taxes are a tax on real estate and any improvements, such as buildings, to that real estate. They are the main resource for local governments' revenues for services. These services include police and fire protection, infrastructure such as roads, water, sewerage, waste, recycling and other utilities, as well as money needed to fund school districts (SPEIRS 2010). A change within the real estate tax system thus makes it possible to increase the income of a municipality, though it requires a reform implemented after a series of preparations have been made.

It is common in Europe to tax real estate according to its value. The practice has quite a long history in many countries. This manner of taxation has been used in Great Britain for about 4,000 years. Other examples include Spain, France, Sweden, the Czech Republic, Slovakia, the USA and Canada. The cadastral tax system can be found in the Baltic states. In 1993, the land tax was introduced in Estonia (with tax fees ranging from $0.1 \%$ to $2.5 \%$ of the estimated land value per year). In Lithuania, this fee equals $1.5 \%$ of the value of privately-owned real estate parcels and from $0.3 \%$ to $1 \%$ of the value of land.

Both of these taxes utilize a series of tax reliefs. Additionally, a large property tax has been introduced in Lithuania on 1 January 2012 - the owners of houses whose value exceeds 1 million litas (approx. 1.25 million PLN) pay 1\% of their value every year. The cadastral tax is also in force in Latvia.

In Germany, Austria and the Netherlands, market prices registered using notarial deeds or taken directly from the land and mortgage registers serve as the basis for taxation. In Ireland, it is the taxpayers who determine the value of the real estate, which in turn is used as the basis for real estate taxation.

The aim of this article is to explain the taxation solutions recognized in Latvia regarding tax fees and the principles of designing taxation maps and tables, as well as problems related to the retrieval of real estate value tax, and then comparing them with the currently established general principles of the cadastral tax.

The scope of the article involves a general explanation of the legal determinants related to common real estate taxation both in Poland and in Latvia. As part of the analysis the authors surveyed people involved in determining the size of the cadastral tax in Latvia. 


\section{The general principles of introducing common real estate taxation in Poland}

Common real estate taxation is defined here as a legal and administrative system aimed at determining real estate value tax, with real estate valuation constituting one of its core elements (SAWIŁOW 2008). Common real estate taxation involves the valuation of numerous real estates, which can be performed individually or en masse.

The first method requires huge expenditures and is difficult to revaluate. It is thus sensible to utilize the other method which, with the use of an appropriate algorithm, enables the estimation of a large number of real estates in a short period of time, using an identical approach. This characteristic manner of valuation requires the use of map and table data, as well as tools to combine these two types of data (TELEGA et al. 2002).

The International Valuation Standards define en masse valuation as the practice of valuating numerous real estates at a given timethrough the systematic and uniform use of methods of valuation which allow for the statistic evaluation and analysis of the results (KUCHARSKA-STASIAK 2005).

The following factors are important as regards the correct manner of performing common real estate taxation:

- each country having a uniform manner of gathering and analyzing data;

- the proper distribution of tasks and responsibilities;

- using proper valuation models;

- evaluating the accuracy of the established data and results.

Determining the cadastral value requires establishing representative real estate. Representative real estate is determined for each type of real estate present in a given taxation zone. In accordance to the Regulation by the Council of Ministers of 29 June 2005 regarding Common Real Estate Taxation (Journal of Laws no. 131, item 1092) a taxation zone is a contiguous area of land which plays an important role in the local spatial development plan, and which possesses similar features contributing to the value of the land.

Two types of land are recognized for taxation purposes: land that is developed or reserved for development, as well as land reserved for purposes other than agriculture or forest management; the other type includes agricultural and forest lands. The starost (district governor) is responsible for all tasks related to performing common real estate taxation. For this purpose, he commissions real estate valuers to determine the cadastral value of representative real estates along with their components, which will serve as the basis for formulating taxation maps and tables.

The procedure of common real estate taxation involves a series of actions including the following elements (WOLANIN 2005):

- determining the value of representative real estate;

- establishing taxation maps and tables and making them accessible to the public;

- approving taxation maps and tables by the town board by means of a resolution and deciding upon the remarks and objections raised regarding the presented taxation maps and tables;

- rendering a decision by the starost and announcing it in the official gazette of the voivodeship.

With traditional property tax, if the landlord makes any improvements, they are reassessed and their tax bill increases. Conversely, if they allow their building to deteriorate, they will ask for a reassessment, and their tax bill will decrease. While there is no direct financial incentive for landlords to maintain their property with an LVT, there is also no financial incentive to purposely allow their properties to fall into disrepair (TANCER 1985).

\section{The cadastral tax in Latvia}

The system of registering real property (which existed before 1940) was re-established after the 1990s. The cadastral system is mainly intended for real property taxation purposes, but it also serves as a tool for the registration of property use and tenure rights, as well as for the storage of technical data, whereas the Land Book system offers corroboration of property rights and registration of any restrictions related to the property (PARSOWA 2012).

From 1990 up to 1997, the people of Latvia were obliged to pay a land tax. But in fact the tax was imposed on land only. Taxes are imposed according to the two main Latvian law regulations, one "on Taxes and Duties" and the other "on Real Property Tax", where real property tax is mentioned. The development of the national cadastral registration system is shown in table 1. 
The development of the national cadastral registration system in Latvia

\begin{tabular}{|c|c|c|c|c|}
\hline No. & Year & Registration system & $\begin{array}{l}\text { Data registration and } \\
\text { processing }\end{array}$ & $\begin{array}{l}\text { Level of } \\
\text { maintenance }\end{array}$ \\
\hline 1. & 1991 & $\begin{array}{l}\text { Registration journal of } \\
\text { land use }\end{array}$ & Manual & Regional \\
\hline 2. & 1992 & Temporary & & Central \\
\hline 3. & 1993 & Cadastre & Digital, Data Flex & Regional \\
\hline 4. & 1993 & Cadastre Register & & Regional \\
\hline 5. & 1998 & $\begin{array}{l}\text { National Real property } \\
\text { information svstem }\end{array}$ & Digital, Oracle (28 databases) & Regional \\
\hline 6. & 2003 & & Digital, Oracle (8 databases) & Regional \\
\hline 7. & since 2007 & & Digital, Oracle (1 database) & Central \\
\hline
\end{tabular}

Source: Parsowa (2012).

Cadastral data from the Cadastre information system are used real estate taxation purposes. Latvian (or foreign) physical and legal persons (or groups of such people) are payers of the tax. The tax is imposed on those who have ownership or legal possession of real property. Only people whose ownership rights have been confirmed in the Land Book are considered as the owners of real property.

For the purposes of cadastral valuation:

- land is divided in accordance with the purpose of use specified for the real property:

- rural land,

- building land;

- buildings are divided into building types, and building types with similar features, which form their value, and ought to be grouped together according to building type;

- engineering structures are divided into types of engineering structures, and engineering structure types with similar criteria, which form their value; they ought to be grouped together according to engineering structure types.

The obligatory tax rates are given below (PARSOWA 2012):

1) The tax rate on the land, buildings or parts thereof and engineering constructions is 1.5 percent of the cadastral value of real property.

2) The tax rate on residential buildings, regardless of whether or not they are used for residential purposes, premises of residential buildings functionally connected with the obeject, as well as premises the functional use of which is associated with living (garages, car parks, basements, storage and utility rooms), if they are not used for economic activities is:

- 0.2 per cent of those for which the cadastral value does not exceed 40,000 LVL,

- 0.4 per cent of those for which the cadastral value is from 40,000 LVL to 75,000 LVL,

- 0.6 per cent of those for which cadastral value exceeds 75,000 LVL.

3) a 1.5 per cent additional tax rate is imposed on unused agriculture land.

The taxation period is a calendar year. Cadastral valuation is a set of operations carried out in order to specify the value of a cadastre object. It is also the systematic valuation of property groups on a particular date, performing the valuation according to a standardized procedure. Such valuation is mainly used for calculating real property tax. Cadastral value ought to be calculated for all cadastre objects and real property registered in the Cadastre information system.

The State Land Service (the "SLS"), as a governmental institution of the Republic of Latvia, is in charge of accumulating data on real properties and its dissemination to institutions responsible for land management and supervision. The SLS is supervised by the Minister of Justice. 
The SLS is also responsible for cadastral valuation according to procedures determined by The Cabinet. What is important, is that information regarding real property transactions is used for at least two years. The SLS registers and analyzes prices on the real estate market, including lease payments, and determines the price level. In order to accumulate and process information regarding real property transactions, the Cadastre information system maintains a database of the real property market.

Lots of data registered in the Cadastre information system are taken into account during the process of calculating cadastral value:

- the base of cadastral value,

- data characterizing the cadastre object,

- intended use of the real property,

- encumbrances on the real property.

The SLS performs the following operations in Cadastre information system (the local government has to administer the tax):

- maintenance of data regarding the real property,

- entering information regarding the payer of the tax.

Worth noting is the fact that cadastral value excludes the value of forestry plantations. Although cadastral value does not include the value of forest stands, their value is also taken into account for taxation purposes. The State Forest Service is the correct institution for carrying out such calculations.

The local government prepares a notice (administrative act) regarding the payment of cadastral tax. Every taxpayer is obligated to pay a tax on the basis of this notice. If a tax payer has not received a payment notice by 15 February of the current assessment year, he has an obligation to inform the local government within one month. The tax shall be paid quarterly, no later than 31 March, 15 May, 15 August and 15 November - in the amount of one quarter of the yearly tax sum. There is also the possibility of paying the tax once a year, by payment in advance.

There are also some opportunities to receive abatements: for real property tax, the amount may be reduced for politically repressed persons - by 50 per cent, but only in cases when the immovable property is not used for economic activity; local governments may accept regulations, which provide abatements for separate categories of taxpayers in the amount of 90 per cent, 70 per cent, 50 per cent or 25 per cent of the tax amount. The maximum abatement (90\%) may be granted to persons with the status of low income households.

The SLS maintains information systems which provide data for the administration of real property tax, involving:

- calculation of the cadastral value for real property taxation purposes,

- gathering information on taxpayers,

- preparing lists of objects real on which real property tax is to be imposed and taxpayers,

- calculation of the total amount of forecasted values of real property.

The SLS has been responsible for calculation of cadastral value only since 2010. In addition to this, it still regularly transfers about 80 percent of data to municipalities, stored in the Cadastre information system.

Cadastral value base - calculating cadastral value requires determining value on the basis of a characteristic set of data (representative real property). The base value and weights of features are determined based on the analysis of real property market data; the established cadastral value pertains to a group of objects which are relatively homogeneous in a given area (zone). Standard methods of valuation recognized in the country, i.e. the pairwise comparison method, income capitalization method and cost approach, are applied to determine cadastral value. Information on real property transactions on the local market from the past two years can be used for this purpose (BAUMANE 2009).

Each of these methods has its own specific approach to obtaining values and own criteria; thus, each of them reflects the value of property rather one-sidedly. Therefore, in order to obtain the most probable value of the property in a particular case, it is desirable to carry out property valuation by various methods (Fig. 1). Comparing the results of each method and analyzing the reliability of the results and impact on the final value will probably produce fairly accurate results. The study hypothesis is that research on real property valuation methods ensures better use of cadastral valuation (BAUMANE 2012). 
All these evaluation methods are based on the comparison principle, differing only in a comparable size. Joint is also the message that anyone that used for evaluating the size must be justified in any area at that time and in the economic situation. The evaluator shall analyze their professionalism within its possession to the property characteristics of the situation in the market and draw conclusions (BALTRUMA, FREIBERGS 1996). The result - the more extensive and more comprehensive the analysis, the more accurate the conclusions derived from it.

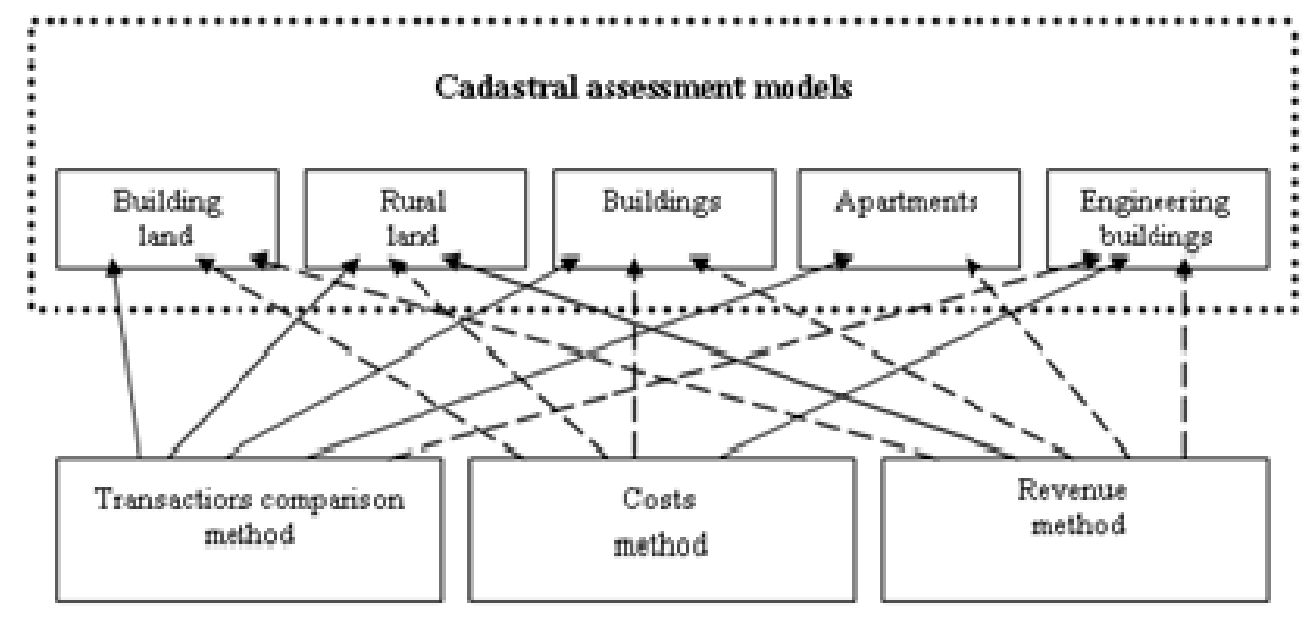

Fig. 1. Cadastral assessment models. Source: Content and application possibilities of evaluation methods in real property cadastral assessment in Latvia. Baltic Surveying'11, International Scientific Conference of Agriculture Universities of Baltic States, Jełgava.

The main principle in the method of pairwise comparison is that a prudent real estate buyer will pay no more than the quality and efficiency similar real estate indicates. This method, also referred to as the market data method consists of three phases:

- finding appropriate reference sites - in this case the location of real estate transactions

- comparison and analysis of the basic choice; the basic choice depends on the type of property, the purposes and the available information, such as:

- ownership (shared ownership lowers the value of the coefficient applied in valuation),

- building or total usable area,

- number of rooms in the dwelling,

- conditions of sale (urgent sale, relationship with business partner, a particular buyer's interest under unusual financial circumstances, etc..),

- location,

- technical condition of the property,

- the application of options (choice of reference objects, whether or not intended use changes after acquisition),

- economic characteristics (the basic unit used to compare revenue generating tools),

- value components that are not directly related to the real property (such as hotels, restaurants, shops/facilities in the area, equipment, furniture, etc.);

- rated object and the reference property values of key factors influencing the determination and the effects of the adjustment to reflect what would be the comparable price of the property, where the basic units of each comparison would be closer, correcting assessed property.

The main problems in the methods use sales data collection and processing. The estimators are able to subscribe to SLS real property market data for information or access the Land Register, however, it is a known fact that most of the information regarding purchase prices is not true. Using information on properties offered on the market but not yet sold may not always produce factual results. Other possible sources of information include real estate firms or private contacts.

Cost method of application of the fundamental principle of real estate valuation is that a prudent buyer of real property will pay no more than he paid for comparable property in a new erection. This method is usually used in the following cases (GLOUDEMAN 1999; BAGDONAVICIUS, DEVEIKIS 2005):

- to evaluate a new, recently built property value, in this case, the depreciation provided for 
errors in the smallest possible;

- to evaluate the special use properties, which are not normally bought or rented (such as schools, hospitals, train stations or churches) and are created for public purposes, not retention, so it is not possible to use the comparison of revenue and methods. In this case, the cost method is the only way to determine the value of the property;

- to compare the obtained results with those of other methods, for example, the relatively high cost methods result might suggest that the market has little competition and future market prices;

- assessing the property markets are inactive, where it is sold very rare and unique objects or in economic activity during periods when the number of sales has fallen sharply;

- to identify the best and most effective use of the property, - for example, to determine what type of building would yield the most profit on a particular piece of land - a small rental house for which the rent would cover the corsts of construction, or a skyscraper in the case of which not leased space would lead to large losses;

- in assessing property tax and for insurance purposes, the cost method provides a separate assessment of both the land and its improvements, which are important in insurance. In some cases, by setting building depreciation, this method is useful in improving the company's balance sheet.

The cost method can be used for the valuation of property which consists of land and buildings, but it is not used for residential property valuation.

\section{Summary}

There are many fears within the Polish society related to changing the taxation system. The cadastral tax was introduced in Latvia in 1990 for land and in 1997 for buildings and structures - changes within the system were first introduced for land. Since 2010, the National Land Service is responsible only for calculating the cadastral value, while all other tasks have been transferred onto the lower levels of the country's territorial division. Forests are an exception to this rule-it is the State Forests which valuate forests for taxation purposes.

The land real estate tax fee introduced in Latvia (1.5\%) seems to be excessive. Using a tax fee of this sort in Poland would result in the manifold increase of the real estate tax, comparable to yearly land perpetual usufruct. These taxes are not paid on buildings and housing units, but for land only.

When introducing taxation system changes in Poland, it seems mandatory to introduce a series of reliefs and exemptions, as well as protection periods. The experience of other countries, including Latvia, which have introduced the cadastral tax serves as a valuable source of guidance on the issue. For buildings unrelated to business activity, the fees in Latvia are dependent on the value of the real estate. If these thresholds were to be transferred onto Polish conditions, they would have the following values in PLN:

- $0.2 \%$ for those buildings and parts of buildings whose book value does not exceed approx. 235,000 PLN,

- $0.4 \%$ for those whose cadastral value falls between approx. 235,000 and 440,000 PLN,

- $0.6 \%$ for those whose cadastral value exceeds 440,000 PLN.

Utilizing the above tax fees under Polish conditions would be a significant burden to households. The cadastral tax, as a property tax, would inevitably lead to a hike in expenses connected with owning real estate. Its implementation is costly and time-consuming. The change would definitely discourage people from investing in the real estate they own, as the tax would continuously rise due to the suffered financial costs. On the other hand, the inflow of real estate tax funds would boost municipal budgets.

Additionally, a change within the taxation system would lead to a revolution in the domain of agricultural and forest real estate taxation, since a reform of this sort would have to apply to all types of real estate. The largest problem connected with switching to this form of real estate taxation in Poland, however, seems to be maintaining complete and legitimate real estate registers.

Land value tax (LVT) is an economic policy tool that can be used to support the objectives of Smart Growth development. Its importance is significant to government finance directors, as well as community and city planners (SPERIS 2010). 


\section{References}

BALTRUMA D., FREIBERGS J., 1996. Kā novērtēt īpašumu. Nekustamā īpašuma vērtēšanas pamatprincipi. Auditorfirma „Invest - Rīga”. 70 lpp.

BAUMANE V., 2009. Improvement of cadastral valuation models. In: Proceedings of the International Scientific methodical Conference: Baltic Surveying 2009. Tartu: Estonia University of Life Sciences, pp. 11.-15

BAUMANE V., 2011. Content and application possibilities of evaluation Methods in real property cadastral assessment in Latvia. Baltic Surveying'11, International Scientific Conference of Agriculture Universities of Baltic States, Jełgava.

GIHRING T. 1999. Incentive Property Taxation: A Potential Tool for Urban Growth Management. Journal of the American Planning Association 65,1; ProQuest Direct Complete (Winter 1999): 63-64.

GLOUDEMAN R., 1999. Mass Appraisal of Real Property. International Association of Assessing Officers pp.428.

HEŁDAK M., 2009. The Management of communal property resource. Studia i Materiały Towarzystwa Naukowego Nieruchomości, vol. 17, nr 3, s. 19-28.

HOZER J., KOKOT S., 2005. Problemy powszechnej taksacji nieruchomości w Polsce. Zeszyty Naukowe Uniwersytetu Szczecińskiego nr 415, Prace Katedry Ekonomii i Statystyki nr 16, s. 135-147.

KRAWCZYK M., 2009. Powszechna taksacja nieruchomości - istota i znaczenie. Ruch Prawniczy, Ekonomiczny i Socjologiczny 71, z. 3. Wydział Prawa i Administracji UAM. S. 49-67.

KUCHARSKA-STASIAK E., 2005. Międzynarodowe Standardy Wyceny. Polska Federacja Stowarzyszeń Rzeczoznawców majątkowych, PFSRM, Warszawa.

PARSOWA V., 2012. Real Property Cadastre in Latvia. Real property Cadastre in Baltic Countries, Jelgava 2012.

SAWIŁOW E., 2008. Metodyka ustalania wartości katastralnej. Studia i Materiały Towarzystwa Naukowego Nieruchomości, vol. 16, nr 3, s. 89-101.

SKABURSKIS A., 1995. The Consequence of Taxing Land Value. Journal of Planning Literature 10; 3 (1995): 3.

SPEIRS M., 2010. Land Value Taxation: An Underutilized Complement to Smart Growth Policies. A project Submitted to The Chair, Department of Community and Regional Planning. In partial Fulfillment of the Requirements for Degree MASTER OF SCIENCE Community and Regional Planning.

TANZER E. P., 1985. The Effect on Housing Quality of Reducing the Structure Tax Rate. Journal of Urban Economics 17(3): 305-318 (1985): 305.

TELEGA T., BOJAR Z., ADAMCZEWSKI Z., 2002. Wytyczne przeprowadzenia powszechnej taksacji nieruchomości (projekt). Przegląd Geodezyjny Nr 6/2002. Wydawnictwo Czasopism i Książek Technicznych SIGMA NOT, Warszawa.

Rozporządzenie Rady Ministrów z dnia 29 czerwca 2005 r. w sprawie powszechnej taksacji nieruchomości (Dz. U. Nr 131 poz. 1092).

Ustawa z dnia 12 stycznia 1991 r. o podatkach i opłatach lokalnych (t.j. Dz. U. z 2010 r. Nr 95 poz. 613 z późniejszymi zmianami).

WOLANIN M., 2005. Powszechna taksacja nieruchomości - zagadnienia materialno-prawne i proceduralne. Nieruchomości, 10(86), Wydawnictwo C.H. Beck, Warszawa.

ŹRÓBEK S., ŻRÓBEK R., KURYJ J., 2006. Gospodarka nieruchomościami z komentarzem do wybranych procedur. Wydawnictwo GALL, Katowice. 